$\begin{array}{ll}\text { INCIH } & \begin{array}{l}\text { Published by } \\ \text { IJCIH \& Pratyaksh Medicare LLP }\end{array} \\ \text { Converging Healthcare \& Technology } & \end{array}$

\title{
The Influence of Health Care Programs on Dengue Hemorrhagic Fever (DHF) Events at Cipamokolan Health Center In Bandung
}

\author{
Agung Sutriyawan ${ }^{1}$, Anri $^{2}$, Hairil Akbar ${ }^{3}$ \\ ${ }^{1}$ Bachelor Programme Public Health, Bhakti Kencana University, Bandung City, Indonesia, ${ }^{2}$ Nursing Faculty, Bhakti \\ Kencana University, Bandung City, Indonesia, ${ }^{3}$ Bachelor Programme Public Health, Institute of Health and Technology \\ Graha Medika, North Sulawesi, Indonesia
}

\begin{abstract}
Background: Dengue is a tropical disease that has become a major international problem in public health in recent years. Currently an estimated 2.5-3 billion people live in dengue transmission zones.

Objectives: The purpose of this study is to find out the effect of health care programs on the incidence of dengue hemorrhagic fever.

Method: The study used control case design. The case population is those who suffer from dengue hemorrhagic fever, while the control population is those who do not suffer from dengue hemorrhagic fever. The case sample in this study was 48 participants and the control group as many as 48 participants. Simple random sampling technique is used to determine research samples, Statistical tests used are chi square tests and odds ratios

Results: The results of the study that had an influence were health counseling (0.000), examination of the flick (0.014), administration of larvacide (0.013), and fogging (0.000).

Conclusion: Health care programs that have been shown to affect the incidence of dengue hemorrhagic fever. are health counseling, larva examination, administration of larvacide, and fogging. To reduce the incidence of dengue hemorrhagic fever needs to be done as early as possible by eradicating the vector of dengue hemorrhagic fever. Health extension activities need to be done to increase public knowledge of the importance of eradicating mosquito nests in efforts to prevent dengue hemorrhagic fever transmission.
\end{abstract}

Keywords: Dengue hemorrhagic fever, health counseling, flick examination, larvacide, fogging.

\section{Introduction}

Dengue hemorrhagic fever (DHF) is a disease caused by the dengue virus, which spreads from person to person

\section{Corresponding Author:}

Agung Sutriyawan

Bachelor Programme Public Health, Bhakti Kencana University, Bandung City, Indonesia

e-mail: agung.sutriawan@bku.ac.id through the bite of the main vector Aedes aegypti. DHF is very common in the tropics and often causes extreme causes. Factors that can affect the development of dengue disease include low population immune status and mosquito breeding density in many places, usually in the rainy season. ${ }^{1}$

Dengue is a tropical disease that has become a major international problem in public health in recent years. Currently an estimated 2.5-3 billion people live in dengue transmission zones. ${ }^{2}$ 
There are 390 million dengue virus infections per year in the world. A dengue prevalence study estimates that 3.9 billion people are at risk of infection, $70 \%$ of the burden of infection being in Asia. ${ }^{3}$ From 2015 to 2019, dengue cases in Southeast Asia increased by $46 \%$ while deaths decreased by $2 \% .{ }^{4}$ Dengue cases in Indonesia were recorded as many as 138,127 cases in 2019 . There was a significant increase in cases from the previous year of 65,602 cases. In addition to the increase in incidence there was also an increase in the case fatality rate (CFR) from 0.65 to 0.94 . While until July 2020 the number of cases reached 71,633 cases. $^{5}$

Bandung is still endemic to DHF. The last two years the number of dengue incidents in the city of Bandung has increased. In 2018 the incidence of DHF was 2,826 cases, 7 of which died. In 2019 there were 4,424 cases, 14 of which died. Almost all areas of Bandung were found cases of DHF, while the highest incidence rate in Kiaracondong, Coblong and Arcamanik districts.

Based on the results of previous research, the current health care program for dengue hemorrhagic fever events include posyandu and the implementation of monthly health services. In addition, because the attention of health workers is focused on the promotion and prevention of environmental health and the implementation of the Disease Eradication Program not been maximized. Preventive health promotion services in collaboration with other stakeholders (including religious leaders and village governments) are most effective in improving health services through dengue prevention. ${ }^{6}$

Prevention is an efficient way to overcome dengue disease, by increasing efforts made to mobilize the community to eradicate mosquito nests through drainage, closure, and use of used products, as well as carrying out the Movement of one house one jumantic to avoid mosquito bites. Monitoring of cases and risk factors for dengue events, including periodic flick monitoring and activation of larva monitoring (Jumantik), and allocation of materials and tools supporting national vector control in the form of pesticides, larva control, jewel mantic kits, sprayers, and media Communication, Information and Education Activities For the prevention of dengue fever disease. $^{7}$
Puskesmas Cipamokolan is one of the endemic areas of DBD incidence, this is seen from dbd cases in 2020 reaching 48 cases so that puskesmas cipamokolan is second in the incidence of DBD in the city of Bandung. Puskesmas efforts are carried out in handling the emergence of dengue cases, namely by conducting health counseling, larva examination by jumantic cadres, fogging and larvacide. Efforts to eradicate DENGUD with PSN efforts are to provide intensive counseling to the community. The main point of the message in counseling delivered is the introduction of dengue symptoms, signs, and ways of preventing transmission in the environment and in their respective homes adapted to education. ${ }^{6}$ Based on the background of the above problems, so the purpose of this study is to know the influence of health care programs on the incidence of dengue hemorrhagic fever.

\section{Material and Method}

This study is an analytical observational quantitative study using case control studies, epidemiological studies that study the relationship of exposure (risk factors) and effects (health problems or diseases), compare case groups with control groups according to exposure conditions. ${ }^{8}$ The study was conducted at Cipamokolan Health Center in April-July 2021.

The population for this study is the community in the working area of Cipamokolan Health Center. The sample in the study was 48 respondents for the case group and 48 respondents for the comparison or control group. Simple random sampling technique is used to determine research samples, with criteria: people ranging in age from 17 years to 55 years, and can speak Indonesian. Data collection using questionnaires, which consists of willingness to be respondents, characteristics of respondents, health services.

The study used desriptive and analytical, descriptive analysis used to look at frequency distribution, as well as chi square tests to look at the relationship of health services to dengue hemorrhagic fever (DHF) incidence. 


\section{Findings}

Table 1. Characteristics of Respondents

\begin{tabular}{|c|c|c|}
\hline Characteristics of Respondents & Frequency & Percentage $(\%)$ \\
\hline \multicolumn{3}{|l|}{ Age } \\
\hline High risk & 60 & 62.5 \\
\hline Low risk & 36 & 37.5 \\
\hline \multicolumn{3}{|l|}{ Gender } \\
\hline Man & 38 & 39.6 \\
\hline Woman & 58 & 60.4 \\
\hline \multicolumn{3}{|l|}{ Education } \\
\hline Primary school & 14 & 14.6 \\
\hline Junior high school & 34 & 35.4 \\
\hline High school & 39 & 40.6 \\
\hline College & 9 & 9.4 \\
\hline \multicolumn{3}{|l|}{ Work } \\
\hline Yes & 56 & 58.3 \\
\hline Not & 40 & 41.7 \\
\hline Total & 96 & 100.0 \\
\hline
\end{tabular}

Table 1 above shows that of the 96 respondents most are high risk age (62.5\%), Most are female (60.4\%), high school education (40.6\%), and most are workers (58.3\%).

Table 2. Overview of Health Counseling, Larva Examination, Larvacide Administration, and Fogging

\begin{tabular}{|c|c|c|}
\hline Health Care Program & Frequency & Percentage $(\%)$ \\
\hline \multicolumn{3}{|l|}{ Health Counseling } \\
\hline Not & 45 & 46.9 \\
\hline Yes & 51 & 53.1 \\
\hline \multicolumn{3}{|l|}{ Larva Examiner } \\
\hline Not & 49 & 51.0 \\
\hline Yes & 47 & 49.0 \\
\hline \multicolumn{3}{|c|}{ Larvacide administration } \\
\hline Not & 41 & 42.7 \\
\hline Yes & 55 & 57.3 \\
\hline \multicolumn{3}{|l|}{ Fogging } \\
\hline Not & 54 & 56.3 \\
\hline Yes & 42 & 43.8 \\
\hline Total & 96 & 100.0 \\
\hline
\end{tabular}

Table 2 above shows that of the 96 respondents, more than half get health counseling from health workers (53.1\%), more than half do not get a larva examination by health workers $(51.0 \%)$, most get larvacides $(57.3 \%)$, and more than half of respondents stated their homes get fogging (56.3\%). 
Table 3. The Effect of Health Care Programs on the Incidence of Dengue Fever

\begin{tabular}{|c|c|c|c|c|c|c|c|}
\hline \multirow{3}{*}{ Health Care Program } & \multicolumn{4}{|c|}{ Dengue Fever } & \multirow{3}{*}{ P-value } & \multirow{2}{*}{\multicolumn{2}{|c|}{ OR $(95 \% \mathrm{CI})$}} \\
\hline & \multicolumn{2}{|c|}{ Case } & \multicolumn{2}{|c|}{ Control } & & & \\
\hline & $n$ & $\%$ & $\mathbf{n}$ & $\%$ & & Lower & Upper \\
\hline \multicolumn{5}{|l|}{ Health Counseling } & \multirow{3}{*}{0,000} & \multirow{3}{*}{\multicolumn{2}{|c|}{$\begin{array}{c}6,600 \\
(1,699-16,137)\end{array}$}} \\
\hline Not & 33 & 68,8 & 12 & 25 & & & \\
\hline Yes & 15 & 31,3 & 36 & 75 & & & \\
\hline \multicolumn{5}{|l|}{ Larva Examiner } & \multirow{3}{*}{0,014} & \multirow{3}{*}{\multicolumn{2}{|c|}{$\begin{array}{c}3,039 \\
(1,323-6,980)\end{array}$}} \\
\hline Not & 31 & 64,6 & 18 & 37,5 & & & \\
\hline Yes & 17 & 35,4 & 30 & 62,5 & & & \\
\hline \multicolumn{5}{|c|}{ Larvacide administration } & \multirow{3}{*}{0,013} & \multirow{3}{*}{\multicolumn{2}{|c|}{$\begin{array}{c}3,122 \\
(1,342-7,263)\end{array}$}} \\
\hline Not & 27 & 56,3 & 14 & 29,2 & & & \\
\hline Yes & 21 & 43,8 & 34 & 70,8 & & & \\
\hline \multicolumn{5}{|l|}{ Fogging } & \multirow{3}{*}{0,000} & \multirow{3}{*}{\multicolumn{2}{|c|}{$\begin{array}{c}9,533 \\
(3,696-24,590)\end{array}$}} \\
\hline Not & 39 & 81,3 & 15 & 31,3 & & & \\
\hline Yes & 9 & 18,8 & 33 & 68,8 & & & \\
\hline
\end{tabular}

Table 3 above shows that health care programs affect the incidence of dengue fever (DBD). Health counseling (0.000), larva examination (0.014), larvacide administration (0.013), and fogging (0.000).

\section{Discussion}

This study examined the health service program against the incidence of dengue in the city of Bandung. The health care programs studied are health counseling, larval examination, larval administration and fogging. The results showed an influence between the provision of health counseling on the incidence of dengue. These results are consistent with previous research that states there is a link between counseling and dengue prevention efforts. ${ }^{9}$ In line with research in Jakarta that states that health education has an effect on the incidence of dengue. ${ }^{10}$

Most of the case group respondents stated that they had not received any health counseling about dengue for the past year. However, most of the control groups have been getting health counseling for the past year. Respondents who have followed health counseling both from government agencies and from private parties will receive information that will then affect behavior changes in a better direction. From the results of the study it is known that most of the respondents mentioned that they had participated in health counseling in the event of a meeting of the Empowerment and Family Welfare Driving Team in their neighborhood. In addition, some respondents who still have children under five have also participated in counseling given by village midwives at posyandu events.

These results are also in line with Green's theory that one of the factors that influences behavior change is health counseling. Health counseling is an educational activity that is carried out by giving a message, instilling confidence, so that the public is not only aware, aware, and understanding but also wants and can do a recommendation that has to do with health which in this case is related to the practice of dengue prevention. ${ }^{9}$

This study proves that the examination of aedes aegepty mosquito larvae periodically affects the incidence of dengue. These results are consistent with previous studies that suggested there is a link between larval examination and dengue incidence. ${ }^{11}$ In line with research in the city of Medan which states that the presence of larvae has a meaningful relationship with the occurrence of dengue disease. ${ }^{12}$

Vector density is one of the risk factors for the spread of DBD cases. High larval density will increase the population of aedes aegypti mosquitoes as a vector of dengue disease in one region. Aedes aegypti mosquitoes are vector DHF in urban areas that have a flying distance 
of about 100 meters. It has great potential to cause extraordinary events of DHF, especially in densely populated residential areas or urban areas. ${ }^{13}$

In addition, climatic conditions also affect the density of DHF vectors. ${ }^{14}$ Rainfall exceeding $200 \mathrm{~mm}$ can also increase the number of dengue cases. ${ }^{15}$ Urban areas with high population density and distance between houses adjacent to each other the potential for mosquitoes causes Ae. aegypti to spread dengue virus will be higher. ${ }^{16}$

The high level of larval density is caused by bad behavior in the eradication of yamuk nests carried out by residents. The number of residents who do not do the eradication of yamuk nests in one area resulted in a high level of larval density. The proportion of the presence of larvae is more found in the population that does not do the habit of eradicating yamuk nests by $80.5 \%$ compared to the population that performs the habit of eradicating yamuk nests by $40.8 \% .{ }^{17}$ Actions in the eradication of yamuk nests are influenced by people's knowledge and attitudes towards DENGUE. High knowledge and positive attitudes increase the actions of the community to do the eradication of yamuk nests. ${ }^{18}$

This study proves the administration of larvacides has an effect on the incidence of dengue. These results are consistent with previous studies stating that there is a relationship between larvacide administration and the incidence of dengue. ${ }^{19}$ In line with other studies that state that sprinkling abate powder is associated with the incidence of dengue. ${ }^{20}$

The use of abate powder at appropriate time intervals and doses was the rarest behavior in the case group and control group. The use of abate powder is one way of eradicating mosquito nests with chemical control. Sprinkling 1 tbsp of abate powder on 100 liters of water in a water reservoir can provide protection for 2-3 months. A mistake that often occurs in respondents is the ignorance of respondents regarding the proper use of abate powder. Irregularity in the use of chemical agents for vector control could in theory trigger resistance. ${ }^{21}$

This study also proved the effect of fogging with the incidence of DHF. These results are consistent with previous research stating that there is a link between foging and the incidence of DHF. ${ }^{22}$ Eradication of Aedes aegypti mosquitoes with fogging (fumigation) was initially considered by the public as the most appropriate way to overcome the problem of dengue fever. This is not always true, because the eradication of Aedes aegypti mosquitoes with this method is only aimed at killing adult mosquitoes that are infective, namely mosquitoes that in the body already contain dengue virus and are ready to transmit to others. While the most important way to overcome/prevent dengue fever disease is the most important is to instill knowledge in the community, so that the community behaves in a healthy life, namely maintaining the cleanliness of the environment that can become a nest - a breeding ground for disease vectors including Aedes aegypti mosquitoes. This is done to break the chain of disease transmission, namely breaking the chain of breeding mosquito larvae into adult mosquitoes. ${ }^{23}$

\section{Conclusion}

Health care programs that have been shown to affect the incidence of dengue hemorrhagic fever are health counseling, jentik examination, larvacide administration, and fogging. To reduce the incidence of dengue hemorrhagic fever needs to be done as early as possible by eradicating the vector of dengue hemorrhagic fever. Health extension activities need to be done to increase public knowledge of the importance of eradicating mosquito nests in efforts to prevent dengue hemorrhagic fever transmission.

Conflict of Interest: All authors have no conflicts of interest to declare.

Source of Funding: The source of this research costs from self.

Ethical Clearance: All subjects were fully informed about the procedures and objectives of the study, each subject prior to the study signed the informed consent form.

\section{References}

1. Farasari R, Azinar M. PocketBook Models and Jentik Monitoring Report cards in Improving Mosquito Nest Eradication Behavior. JHE (Journal of Health Education). 2018;3(2):110-7.

2. Sutriyawan A, Kurniawati RD, Suherdin S. Projection and Mapping of Dengue Hemorrhagic Fever (DHF) Cases Based on Geographic Information Systems (GIS). Afiasi: Journal of Public Health. 2021;6(2):7181. 
3. WHO. Dengue and severe dengue [Internet]. WHO. 2021 [cited 2021 Dec 28]. Available from: https:// www.who.int/news-room/fact-sheets/detail/dengueand-severe-dengue

4. WHO. Dengue in the South-East Asia [Internet]. WHO. [cited 2021 Dec 28]. Available from: https:// www.who.int/southeastasia/health-topics/dengueand-severe-dengue

5. Ministry of Health of the Republic of Indonesia. Indonesia Health Profile 2019. In Jakarta: Ministry of Health of the Republic of Indonesia;

6. Oroh MY, Pinontoan OR, Tuda JBS. Environmental, Human and Health Services Factors Associated with Dengue Hemorrhagic Fever. Journal of Public Health and Community Medicine. 2020;1(3):35-46.

7. Ministry of Health of the Republic of Indonesia. Ministry of Health Issues Circular Letter on Eradication of Mosquito Nests with 3M Plus and Movement 1 House 1 Jumantik [Internet]. 2016. Available from: https://www.kemkes.go.id/article/ view/16121400002/kemenkes-keluarkan-suratedaran-pemberantasan-sarang-nyamuk-dengan-3mplus-dan-gerakan-1-rumah-1-jum.html

8. Sutriyawan A. Medical and Health Research Methodology: Equipped with Guidance to Make Research Proposals. Bandung: PT. Repika Aditama; 2021.

9. Dewi NP, Azam M. Factors related to family PSNDBD practices in Mulyoharjo village. Public Health Perspective Journal. 2017;2(1).

10. SUTRIYAWAN A, ABA M, HABIBI J. DETERMINANTS OF DENGUE HEMORRHAGIC FEVER (DENGUE) EPIDEMIOLOGY IN URBAN AREAS: RETROSPECTIVE STUDY. Journal of Nursing and Public Health. 2020;8(2):1-9.

11. Sari P. Relationship of aedes sp flick density and PSN practice with DHF incidence at elementary school in Semarang City. Journal of Public Health, Diponegoro University. 2012;1(2):18737.

12. Parida S, Dharma S, Hasan W. The Relationship of the Existence of Aedes Aegypti And the Implementation of $3 \mathrm{~m}$ Plus with the Incidence of DHF Disease in the XVIII Environment of Binjai Village of Medan City in 2012. Environment and Safety. 2012;2(2):14633.

13. Toan DTT, Hoat LN, Hu W, Wright P, Martens P. Risk factors associated with an outbreak of dengue fever/dengue haemorrhagic fever in Hanoi, Vietnam. Epidemiology \& Infection. 2015;143(8):1594-8.

14. Puspita T, Ariati J, Perwitasari D. Climatic conditions and patterns of dengue hemorrhagic fever incidence in yogyakarta city in 2004-2011. Media Research and Health Development. 2015;25(4):20748.

15. Williams CR, Mincham G, Ritchie SA, Viennet E, Harley D. Bionomic response of Aedes aegypti to two future climate change scenarios in far north Queensland, Australia: implications for dengue outbreaks. Parasites \& vectors. 2014;7(1):1-7.

16. Santoso S, Margarety I, Taviv Y, Wempi IG, Mayasari $\mathrm{R}$, Marini M. The characteristic relationship of containers with the presence of Aedes aegypti flicks on the extraordinary incidence of Dengue Hemorrhagic Fever: case studies in Ogan Komering Ulu Regency. Journal of Vectors of Disease. 2018;12(1):9-18.

17. Imawati D, Sukesi TW. Factors related to the existence of jentik in Mandingan Village Kebon Agung District Imogiri Bantul Regency. J Med Respati. 2015;10(2):78-89.

18. Monintja TCN. The relationship between individual characteristics, knowledge and attitudes with the actions of PSN-DBD community Malalayang village I Malalayang district manado city. Jikmu. 2015;5(5).

19. SUTRIYAWAN A. PREVENTION OF DENGUE HEMORRHAGIC FEVER (DHF) THROUGH ERADICATION OF MOSQUITO NESTS. Journal of Nursing and Public Health. 2021;9(2):1-10.

20. Winarsih S. Relationship of Home Environmental Conditions and PSN Behavior with DHF Events. Unnes Journal of Public Health. 2013;2(1).

21. Priesley F, Reza M, Rusdji SR. The relationship of mosquito nest eradication behavior by closing, draining and recycling plus (PSN M Plus) to the incidence of dengue hemorrhagic fever (DHF) in Andalas Village. Andalas Health Journal. 2018;7(1):124-30.

22. Jaya DR, Zainal S, Djewarut H. The relationship between prevention efforts and dengue fever incidence in Tritiro village of Bontotiro Health Center, Bontotiro District, Bulukumba District. Journal of Scientific Health Diagnosis. 2013;3(3):9-17.

23. Kusumawati Y, Suswardany DL, Yuniarno S, Darnoto S. Efforts to eradicate Aedes Aegypti mosquitoes with fogging in order to prevent an increase in dengue fever cases. Warta LPM. 2007;10(1). 